\title{
Managerial Ownership and Supervisory Board Activity: Evidence from Polish Listed Companies
}

\begin{abstract}
This study examines the relationship between managerial ownership and supervisory board activity in the Polish two-tier board model. It reveals that managerial ownership has a negative influence on supervisory board meeting frequency and the number of supervisory board committees.
\end{abstract}

Keywords: corporate governance, managerial hegemony theory, ownership structure, two-tier board model, Poland.

Šiame tyrime nagrinejjami tarpusavio veiklos santykiai egzistuojantys tarp bendrovès savininkų valdybos ir priežiūros tarybos narių Lenkijos dviejų valdymo pakopų modelyje. Straipsnyje atskleidžiama, kad nuosavybẻs valdymas turi neigiamos ịtakos priežiūros tarybos posèdžių dažnumui ir tarybos narių skaičiui.

Raktiniai žodžiai: bendrovės valdymas, valdymo hegemonijos teorija, nuosavybės struktūra, dviejų pakopų modelis, Lenkija.

\section{Introduction}

The role of corporate boards has been one of the most debated issues by scholars and practitioners in corporate governance. They acknowledged the importance of the boards' monitoring function (Zahra, Pearce, 1989; Baysinger, Hoskisson, 1990), their contribution to strategy formulation (Pugliese et al., 2009; Tricker, 2009) and the boards' involvement in providing resources (Hillman, Cannella, Paetzold, 2000; Pfeffer, Salancik, 1978) long ago. But the previous findings of studies on the role of boards, seems to be ambiguous. While some authors mention that boards of directors are a powerful internal governance mechanism which tends to align the interests of shareholders and managers (Oviatt, 1988), are able to support management in strategy formulation (Stiles, 2001; Bezemer et al., 2007) and have ultimate control over management through their capacity to hire or fire the chief executive officers (Mizruchi 1983), other studies also underline that corporate boards are passive, reactive, ineffective, not involved in strategic decision 
making process and, in addition, dominated by executives (Kosnik, 1987; Lorsch, MacIver, 1989). This ambiguity may result from the reliance on an explicitly single theoretical framework, which needs not to be universal.

However, to date the discussion on the activity of corporate boards has been mostly stimulated by agency theory perspective (Jensen, Meckling, 1976; Eisenhardt, 1989). Accordingly, most studies have examined the relationships between board structure, tasks and processes and company performance (Kiel, Nicholson, 2003; De Andres, Azofra, Lopez, 2005). But there are also other theoretical perspectives which may be appropriate in describing board roles in different institutional conditions. The present study is fueled by managerial hegemony theory (Mace, 1971; Lorsch, MacIver, 1989), which seems to be useful for depicting the relationship between managers and supervisory board members in companies with significant managerial ownership. Hence, the present understanding of the role of corporate boards is full of gaps. Firstly, most studies have focused on one-tier boards, while little is known about two-tier boards. This especially applies to the efficiency and activity of upper boards, i.e. supervisory boards. The studies conducted so far have generally found these boards to be passive, but have not explored the underlying causes of this state of affairs (Rudolf et. al., 2002; Aluchna, 2007; Jezak, 2010). In contrast, the present study is intended to provide indepth insights and show how often board members meet and how they fulfill their functions. Second, as has been mentioned, most previous studies were based on the agency perspective. This study draws on managerial hegemony theory and shows how managerial ownership reduces the role of corporate boards. Anyway, this paper seeks the sources of this phenomenon in the problems described by managerial hegemony theory. Generally, the purpose of this paper is to investigate how managerial ownership affects supervisory board activity.

The paper is organized as follows. Firstly, managerial hegemony theory is described. It sheds some light on the role of supervisory boards. Secondly, the specificity of the Polish two-tier board model is discussed, including its main features, the functions of the supervisory and management boards, and the advantages and disadvantages of two-tier boards. Thirdly, hypotheses are developed on the relationship between managerial ownership and supervisory board activity. These sections are followed by the research methodology section and findings from the study. Finally, a summary and conclusions, including research limitations, is presented.

\section{Literature review}

\subsection{Managerial hegemony theory}

Managerial hegemony theory perceives the role of board members instrumental and recognizes corporate boards as a tool for supporting managerial decisions (Hung, 1998). This theory refers to a situation where strategic decisions are directed by professional managers who are in a superior position within companies. R. D. Kosnik (1987) mentioned that managerial hegemony describes the board as "a co-opted appendage institution that, despite its formal governing power over management, is in fact dominated by corporate managements, hence, ineffective in 
alleviating conflicts of interests between management and stockholders". This indicates that perhaps in literature, the role of the corporate boards is overemphasized. Thus, M. L. Mace (1971) noted a gap between the myths of business literature and practice - a discrepancy between what directors should do and what they do in reality. He called board members "ornaments on a corporate Christmas tree" and boards of directors "old boys clubs" and "rubber stamps". Also P. Drucker (1974) described boards of directors as "an impotent ceremonial and legal fiction".

This theory identifies deficiencies of corporate boards in management control, amongst others, over the selection of external directors. Top managers can co-opt compliant external directors, who do not have the desire or strength to oppose the proposals of top managers and substantially rubber stamp management's policies (Kosnik, 1987). J. W. Lorsch and E. MacIver (1989) pointed out that external board members face some constraints in fulfilling their duties, such as their available time and knowledge, a lack of consensus about their goals and the superior power of management. Also R. D. Kosnik (1987) listed reasons for passive behaviour of corporate boards, which are: relative lack of knowledge about the company's affairs, dependence on information and insights that are provided by the company's top managers and the directors' interests in the benefits that ensue from board membership, e.g. compensation and prestige.

Corporate governance has been dominated by the agency theory. Particular attention was paid to board independence (Rosenstain, Wyatt, 1990; Westphal, Zajac, 1997). During this time, managerial hegemony theory remained on the sidelines. However, this theory indicates some problems within corporate boards, which in some countries and companies can be of great importance. This is the same for the two-tier board model and companies in which a significant share of ownership lies with the managers. Here the role of supervisory boards may be limited to being "rubber stamps" and "ornaments on a corporate Christmas tree".

\subsection{Polish two-tier board model}

In Poland companies are required to have a two-tier board structure with a supervisory board and a management board. The supervisory board consists solely of external directors and is comprised of a minimum three members in private companies and of a minimum five members in listed companies. These are convened by the annual general meeting. The management board is entirely composed of internal directors and consists of one or more members. Management board members are called by the supervisory board. Articles of the association can allow for other ways of their appointment, i.e. by general meeting. Two-tier boards in Europe can also be found for example in Germany, Austria, the Czech Republic and Slovakia, but unlike these countries in Poland workers are not entitled do delegate their representatives to supervisory boards (The European Commission, 2009).

In accordance with Polish company law, the management board is responsible for managing the company. It is the real decision-making body, which is responsible for the formulation of strategy and for operations. The supervisory board exercises day-to-day supervision in all areas of the company's activity. Its duties also include the granting of contracts to members of the management board, approving 
the most important strategic and financial decisions, reviewing the firm's performance with the management board, approving annual reports, and selecting auditors (Kojima, 1997). In Poland, the responsibilities of the supervisory board can be broadened by shareholders through provisions contained in the articles of association. It is commonly found that their duties also include entering into contracts with top managers, approving long-term plans and annual budgets, selecting external auditors, representing companies in disputes with their management, approving issue prices, accepting unified texts of the articles of association, granting approval for the purchase or sale of real estate, giving investment guarantees, assuming financial obligations, raising equity capital, purchasing shares of significant value, purchasing or selling movables, establishing or liquidating company divisions, setting up new subsidiaries, granting procuration, and sale of preferred shares or their exchange for ordinary shares (Bohdanowicz, 2009; Jezak, 2010).

The positive and negative features of the two-tier board model have been specified by A. Cadbury (2002), M. Spisto (2005) and C. Jungmann (2006). Under the twotier model, the supervisory and management functions are strictly separate and both boards consist of different members. As a result, members of the supervisory board are theoretically independent from managers. Moreover, members of the supervisory board are appointed by shareholders. They in turn appoint members of the management board. The link between the owners, supervisors and managers is obvious. Thanks to this, members of both boards avoid conflicts of loyalty. On the other hand, the division of supervisory and management functions seems to be the cause of weaknesses of the two-tier board model. Supervisory boards always behave in a reactive way and are seen as passive organs. They do not boost the company's status, but are rather restricted to making comments on the adopted solutions and, if necessary, they can dismiss members of the management board. Moreover, there is strong information asymmetry between the management board and the supervisory board as all information considered during supervisory board meetings is delivered by the management board, which can jeopardize the process of deficiency discovery by the supervisory board due to a lack of adequate information.

\subsection{Managerial ownership and board activity}

In literature board activity was used to examine corporate boards' ability to fulfill its control function and subsequent impact on the company's strategy. Control function is perceived as the most important board function, especially in two-tier board model (Tricker, 2009). Accordingly, K. Menon and J. D. Williams (1994) stated that board audit committees, which do not meet or do not meet often, are dubious as effective monitoring bodies. F. Zona, A. Zattoni and A. Minichilli (2013) concluded that boards, which meet episodically, seldom explore the in depth aspects of strategic decisions, including innovation strategy. Though, previous research supported the view that board activity is a significant dimension of board operations, has a positive impact on company value, and is driven by merger and acquisition activity and by accounting restatements (Vafeas, 1999; Brick, Chidambaran, 2010). Moreover, it prevents omissions 
which may take place in the financial reporting process (Carcello et al., 2002) and contributes to greater transparency of the executive remuneration (Laksamana, 2008).

Generally as a proxy for the level of boards' monitoring activity, their meeting frequency was used. For example N. Vafeas (1999) utilized the board meeting frequency as a proxy for board activity and found that the lower the number of meetings the higher the book value displayed. Moreover, he also supported the view that managerial ownership had a negative relationship with the frequency of board meetings. This is consistent with A. Shleifer and R. W. Vishny (1997) conclusion based on the agency theory that insider shareholders exercise direct supervision on management or are managers themselves. Moreover, when ownermanagers are dominant shareholders, this can lead to further consequences, because dominant shareholders may attempt to maximize their own utility and expropriate wealth from minority shareholders (Shleifer and Vishny, 1997; Holderness, 2003). Their superior position is possible, when corporate boards as controlling bodies are undermined.

However, G. Greco (2010) found that insider ownership negatively impacts boards of directors and the audit committee meeting frequency. In addition he found that audit committees are more active in large companies and there is a positive relationship between the proportion of independent directors and board activity, but in contrast to N. Vafeas (1999) he did not find evidence that boards are more active in consequences to problems within companies or in decreasing their performance. Similar results were obtained by C. F. Mendez and R. A. Garcia
(2007) who found a negative relationship between insider shareholdings and the audit committee frequency.

Hence, this research is concentrated on supervisory board activity in the two-tier board model. Due to this the hypothesis can be put forth simply as follows: managerial ownership diminishes supervisory board activity and makes it passive. More specifically, managerial ownership negatively affects supervisory board meeting frequency and the number of supervisory board committees, which is used as the second proxy for the intensity of supervisory board activity.

\section{Research results and discussion}

\subsection{Research sample and variables}

The sample consists of Polish companies listed on the Warsaw Stock Exchange between 2010 and 2012. The adoption of this period depended on the availability of data. Data was hand-collected and derived from annual reports. The sample involves only non-financial companies. Financial institutions are excluded due to their unique financial structure and special accounting rules which apply to the financial sector. Observations with missing data are also excluded. This gives an unbalanced initial panel sample of 207 companies and 463 firm-year observations.

The following model has been used for testing the hypothesis:

$$
\mathrm{Y}_{\mathrm{it}}=\alpha_{\mathrm{i}}+\beta \mathrm{X}_{\mathrm{it}}+\gamma \mathrm{Z}_{\mathrm{it}}+\varepsilon_{\mathrm{it}}
$$

where: the $\mathrm{Y}_{\mathrm{it}}$ vector contains dependent variables, i.e. proxies for supervisory board activity (supervisory board meeting frequency and number of supervisory board committees); $\mathrm{X}_{\text {it }}$ represents the independent variable, i.e. a proxy for 
managerial hegemony (managerial ownership); $Z_{i t}$ consists of control variables, that is supervisory board diversity, supervisory board size, management board size, firm size, debt ratio, and firm performance (i.e. return on assets), and $\varepsilon_{\text {it }}$ describes random disturbance.

Since the data span covers three years, this is analyzed using panel data analysis (a fixed-effects model). This method takes into account individual effects and allows for controlling changes in the behaviour of units over time (Gujarati, 2003). Moreover, using the panel increases the number of degrees of freedom and reduces collinearity between independent variables, which leads to a higher estimation efficiency and to a determination of their real impact on the dependent variables (Hsiao, 2003; Maddala, 2008). The analysis carried out in this way also enables the elimination of heterogeneity resulting from the occurrence of unobservable factors (or those not included in the model) which might differentiate individual units (e.g. unquantifiable factors). This is important because heterogeneity leads to biased estimators (Green, 2003).

Three main variables of interest are the number of meetings held by the supervisory board annually as disclosed in annual reports from the supervisory boards and number of supervisory board committees, which are dependent variables, and managerial ownership, which is an independent variable. The number of meetings held by the supervisory board was used as a proxy for the intensity of board activity by N. Vafeas (1999) and I. E. Brick and N. K. Chidambaran (2010). Similarly this study excludes actions by written consent, telephonic meetings and video teleconferences because it is more challenging to fulfil board functions from distance (Vafeas, 1999). As a second proxy for board activity the number of committees is used. In prior research the frequency of committee meetings was rather used as this proxy, but in Poland this is not often disclosed. Generally, the board committee establishment helps to improve corporate governance by delegating particular tasks from the whole board to the smaller group of boards' members (Spira, Bender, 2004; Koladkiewicz, 2011). Thus even the establishment of a committee helps to increase the intensity of supervisory board activity. Managerial ownership is the percentage of shares owned by all management board members. This variable is calculated as direct and indirect voting rights at the general meeting and counted as a decimal number.

The choice of control variables is motivated by their potential relevance. The board size is commonly defined as the total number of directors (Florackis, Ozkan, 2009), but since a two-tier board model is being studied, it has to be measured using two variables, i.e. the total number of directors on supervisory boards and the total number of directors on management boards. Moreover, while we are witnessing the growth of research on board diversity and its influence on company performance and various board processes (Nielsen, Huse, 2010; Terjesen, Sealy, Singh, 2009), board diversity is employed to control its impact on board activity. As a proxy for board diversity, the author of this paper used the percentage of women on the supervisory board (Campbell, Minguez-Vera, 2008). This variable is also calculated as a decimal number. In view of the fact that the company size is associated with board activity, we may use total assets at the end of the firm's prior fiscal year as a control variable and a proxy for 
the scale of the company. As it is commonly done, this is transformed with a natural logarithm (Brick, Chidambaran, 2010; Kang, Cheng, Gray, 2003; Kochhar, David, 1996). To control company leverage, debt ratio is used. This is calculated as the ratio of total liabilities to total assets. Moreover, this is included in the Return on Assets (ROA) as a measure of company performance.

\subsection{Descriptive statistics}

Table 1 shows descriptive statistics for the variables considered. They are given as averaged for all three years. The supervisory board meeting frequency across the entire sample is 6.4276 with standard deviation 3.43 . The average numbers of meetings of the Polish supervisory boards is lower than the average number of meetings of boards of directors in a similar studies by N. Vafeas (1999), where it was 7.45 meetings, and G. Greco (2010), where it was 9.27 meetings. These differences arise from the difference in functions of boards of directors in a one-tier board model and supervisory board in a two-tier board model. B. Tricker (2009) indicated that boards of directors perform four functions, i.e. accountability, strategy formulation, policy making and supervising executive activities, while supervisory boards mainly concentrate on supervising executive activities. The average number of supervisory board committee's amounts 0.7451 . Moreover, more than half of the companies in the sample have no board committee. By contrast, N. Vafeas (1999) reported that the average number of standing board committees was 4.29 in his research. Managerial ownership in the sample is relatively high. The mean is 0.1944 , which is higher than reported by N. Vafeas (1999), but lower than reported by G. Greco (2010) for Italian companies. It can be concluded that managerial ownership is significant in Poland, but not as dominant as for example in Italy.

On average there are approximately 6 directors that serve on the supervisory board and 3 on the management board. Precisely, the mean of the supervisory board size is amounted 5.7343 with standard deviation 1.2045 and the mean of management board size is 3 with standard

\section{Descriptive statistics}

Table 1

\begin{tabular}{|l|c|c|c|c|}
\hline \multicolumn{1}{|c|}{ Variable } & Mean & Standard deviation & $\mathbf{1 0}^{\text {th }}$ percentile & $\mathbf{9 0}^{\text {th }}$ percentile \\
\hline $\begin{array}{l}\text { Supervisory board mee- } \\
\text { ting frequency }\end{array}$ & 6.4276 & 3.43 & 3.0 & 11.0 \\
\hline $\begin{array}{l}\text { Number of supervisory } \\
\text { board committees }\end{array}$ & 0.7451 & 0.8948 & 0.0 & 2.0 \\
\hline Managerial ownership & 0.1944 & 0.2714 & 0.0 & 0.6794 \\
\hline Supervisory board size & 5.7343 & 1.2045 & 5.0 & 7.0 \\
\hline $\begin{array}{l}\text { Supervisory board } \\
\text { diversity }\end{array}$ & 0.1427 & 0.1699 & 0.0 & 0.4 \\
\hline Management board size & 3.0 & 1.3691 & 2.0 & 5.0 \\
\hline Company performance & 0.0148 & 0.1408 & -0.0805 & 0.1106 \\
\hline Debt ratio & 0.4944 & 0.4338 & 0.2163 & 0.7137 \\
\hline Company size & 19.4359 & 1.6936 & 7.4766 & 21.6666 \\
\hline
\end{tabular}

Source: the author's calculations based on data extracted from annual reports. 
deviation 1.3691. Moreover, it is worth underlining that the lowest number of supervisory and management board members in Poland are limited by the company law. Polish supervisory boards of listed companies should consist of five or more members and management boards of one or more members. This shows that in particular supervisory boards of many companies consist only of a minimum number of members. Moreover, the mean of supervisory board diversity is 0.1427 . Thus, women denominate slightly more than $14 \%$ of the supervisory board members, which is consistent with the results of other similar studies carried out in Poland (Bohdanowicz, 2012). The average debt ratio is 0.4944 and the mean natural logarithm of total assets (company size) is 19.4359. Furthermore, the mean of return on assets is 0.0148 .

\subsection{Multivariate test}

Table 2 illustrates the results of panel data estimation for the sample. The results reveal that the interaction between managerial ownership and supervisory board meeting frequency is negative and significant $(\beta=-3.2767, \mathrm{p}<0.1)$ and the relationship between managerial ownership and the number of supervisory board committees is also negative and significant $(\beta=-0.5977$, $\mathrm{p}<0.01)$. These findings support the hypothesis that managerial ownership diminishes supervisory board activity and specifically that managerial ownership negatively affects supervisory board meeting frequency and the number of supervisory board committee. These results are also consistent with N. Vafeas's (1992), C. F. Mendez and R. A. Garcia's (2007) and G. Greco's (2010) findings. They show that managerial ownership reduces the activity of supervisory boards and their ability to fulfil their control function.

The analyses identifies three relationships between some of dependent and control variables. They include a negative relationship between supervisory board meeting frequency and company size $(\beta=-1.6378, p<0.01)$. This relationship is the opposite direction than the relationship noticed in I. E. Brick and N. K. Chidambaran's (2010) study where it was statistically significant. But at the same time in N. Vafeas's (1999) and G. Greco's (2011) research this relationship was not statistically significant. A sign found in this present study may result from the structure of the sample. Large Polish companies have concentrated ownership, and the dominant shareholders can directly control the companies without increasing the activity of corporate boards (Mendez, Garcia, 2007). Moreover, there is a positive relationship between the number of supervisory board committees and supervisory board size $(\beta=0.1303, \mathrm{p}<0.001)$. This is due to the fact that to be more effective, large boards appoint various sub-committees and entrust them with some activities, although the supervisory boards as a whole are responsible for the functions performed by these sub-committees (Colley et al., 2005; Mallin, 2009; Koladkiewicz, 2011). Furthermore, it shows that there is a negative relationship between the number of supervisory board committees and debt ratio $(\beta=-0.3411, \mathrm{p}<0.05)$.

\section{Conclusions and discussion}

Due to the fact that corporate boards are recognized by managerial hegemony 
Panel data estimation

Table 2

\begin{tabular}{|l|c|c|}
\hline \multirow{2}{*}{ Independent and control variables } & \multicolumn{2}{|c|}{ Dependent variables } \\
\cline { 2 - 3 } & $\begin{array}{c}\text { Supervisory board meeting } \\
\text { frequency }\end{array}$ & $\begin{array}{c}\text { Number of supervisory } \\
\text { board committees }\end{array}$ \\
\hline \multirow{2}{*}{ Managerial ownership } & $-3.2767 \dagger$ & $-0.5977^{* *}$ \\
& $(1.9479)$ & $0.2435)$ \\
\hline \multirow{2}{*}{ Supervisory board meeting frequency } & - & 0.0056 \\
& & $(0.00801)$ \\
\hline \multirow{2}{*}{ Number of supervisory board committees } & 0.3516 & - \\
\hline \multirow{2}{*}{ Supervisory board size } & $(0.5095)$ & $0.1303^{* * *}$ \\
& 0.1209 & $0.0387)$ \\
\hline \multirow{2}{*}{ Management board size } & $(0.3146)$ & 0.0307 \\
& -0.2388 & $0.0295)$ \\
\hline \multirow{2}{*}{ Supervisory board diversity } & $(0.2343)$ & 0.2523 \\
& 0.9494 & $(0.2117)$ \\
\hline \multirow{2}{*}{ Company performance $($ ROA $)$} & $(1.6867)$ & -0.2197 \\
& -2.0368 & $(0.1585)$ \\
\hline \multirow{2}{*}{ Debt ratio } & $(1.2578)$ & $-0.3411^{*}$ \\
& 0.0381 & $(0.1811)$ \\
\hline Company size & $(1.4503)$ & 0.0030 \\
& $-1.6378^{* *}$ & $(0.1000)$ \\
\hline \multirow{2}{*}{ Constant } & $(0.7883)$ & 0.0491 \\
& $38.5523^{* *}$ & $(1.9221)$ \\
\hline Adjusted R-squared & $(15.0779)$ & $0.9319^{* * *}$ \\
\hline
\end{tabular}

Note: $\dagger p<0.1 ;{ }^{*} p<0.05 ;{ }^{* *} p<0.01$; ${ }^{* \star *} p<0.001$. Standard error is given in brackets.

Source: the author's calculations based on data extracted from annual reports.

theory as rather passive, it is essential to examine what leads to their inactivity. This study investigates how managerial ownership influences the activity of supervisory boards of Polish listed companies. The results reveal negative interactions between managerial ownership, the frequency of supervisory board meetings, and the number of board committees. The results also demonstrate that owner-managers can reduce supervisory board activity in listed companies. N. Vafeas (1999) explained this relationship on the basis of the agency theory and suggested that board activity is a substitute for the high level of inside ownership in disciplining management. This does not have to be, and this mechanism may act as a double-edged sword. Many studies show that the concentration of ownership also in hands of managers may not necessarily lead to maximization of wealth for all shareholders, but rather towards a danger of abuses against minority shareholders (Shleifer, Vishny, 1997; Holderness, 2003). Moreover, the relationship between managerial ownership and firm performance is ambiguous. Some studies found the nonlinear and negative at high concentration of ownership relationship (Morck, Shleifer, Vishny, 1988; Hermalin, Weisbach, 1991). 
Managerial ownership reinforces the problem noted by M. Jensen (1993). According to him, the CEO almost always set the agenda for board meetings. This applies to the one-tier model, where the $\mathrm{CEO}$ is a member of the board of directors and often controls it. This problem occurs also in the two-tier board model. This is noticed by J. Jezak (2010), who states that the agenda for the meeting and the information for the supervisory boards are prepared by the management boards, which often leads to the presentation of incomplete information. In view of this, the negative relationship between managerial ownership and supervisory board activity support managerial hegemony theory and the conclusions formulated by M. L. Mace (1971) and J. W. Lorsch and E. MacIver (1989). The increase in managerial ownership makes the supervisory board become rubber stamps and "ornaments on a corporate Christmas tree". They mainly meet to approve decisions submitted by managerowners. There are two reasons for this, i.e. legally defined functions and responsibilities of the supervisory boards and the desire to dominate the supervisory boards by managers. Especially since the law in Poland does not give the strong position of supervisory boards leaving a lot of discretion for the company's bylaws (Aluchna, 2009)

In view of this, this study may be used as a starting point for a discussion on institutional changes in the Polish two-tier board model and other countries with implications for the public authorities that are currently carrying out corporate governance reforms. Firstly, one should consider the introduction of an optional board model (a choice between one-tier and two-tier board models). An optional model allows for flexible adaptation of corporate board structure and model to the ownership structure, the type of sector, as well as the size and scope of activities. Secondly, it would be advisable to impose similar liability on internal and external directors. In this case, external directors would be less willing to tolerate a decrease of the supervisory board activity. In addition, if the activity of the supervisory boards was less, it could be an incentive for their members to be removed or denied seats on the supervisory board. The result would be a signal to investors who would be at a greater risk of Investment in shares of the company.

The results of this study are also subject to limitations associated with the measurement of variables and the method used. The first limitation concerns missing data. Many Polish companies did not disclose the number of meetings of the supervisory board. This could also affect the lower level of statistical significance when testing the relationship between managerial ownership and the meeting frequency of the supervisory boards than in similar studies carried out in the one-tier board model (Vafeas, 1999; Greco, 2010). The second limitation relates to the proxy used, i.e. the number of supervisory board committees. It would be better to use the number of committee meetings, as did G. Greco (2010). Unfortunately, companies in Poland, most frequently give only the number of committees and their type, but unfortunately very rarely the number of meetings of these committees. 


\section{References}

1. Aluchna, M. (2007). Mechanizmy corporate governance w spolkach gieldowych. - Warszawa: Szkola Glowna Handlowa w Warszawie.

2. Aluchna, M. (2009). Does good corporate governance matter? Best practice in Poland // Management Research News. Vol. 32. No. 2, pp. 185198. doi: 10.1108/01409170910927631.

3. Baysinger, B., Hoskisson, R. E. (1990). The composition of boards of directors and strategic control: Effects on corporate strategy // Academy of Management Review. Vol. 15, No. 1, pp. 72-87.

4. Bezemer, P., Maassen, G. F., Van Den Bosh, F. A. J., Volberda, H. W. (2007). Investigating the development of the internal and external device task of non-executive directors: The case of the Netherlands (1997-2005) // Corporate Governance: An International Review. Vol. 15, No. 6, pp. 11191129. doi: 10.1111/j.1467-8683.2007.00635.x.

5. Bohdanowicz, L. (2009). Profesjonalizm w funkcjonowaniu rad nadzorczych spolek akcyjnych. - Lodz: Wyd. UL.

6. Bohdanowicz, L. (2012). Ownership Structure and Female Directors on Two-Tier Boards: Evidence from Polish Listed Companies. - Working Paper, Internet access: <http://dx.doi. $\operatorname{org} / 10.2139 /$ ssrn.2117870 >, [accessed July 26, 2012].

7. Brick, I. E., Chidambaran, N. K. (2010). Board meetings, committee structure, and firm value // Journal of Corporate Finance. Vol. 16, pp. 533553. doi: 10.1016/j.jcorpfin.2010.06.003.

8. Cadbury, A. (2002). Corporate Governance and Chairmanship: A Personal View. - Oxford: Oxford University Press.

9. Campbell, K., Minguez-Vera, A. (2008). Gender Diversity in the Boardroom and Firm Financial Performance // Journal of Business Ethics. Vol. 83, No. 3, pp. 435-451. doi: http://dx.doi. org/10.1007/s10551-007-9630-y.

10. Carcello, J. V., Hermanson, D. R., Neal, T. L., Riley, R. A. (2002). Board characteristics and audit fees // Contemporary Accounting Research. Vol. 19, No. 3, pp. 365-384. doi: 10.1506/CHWKGMQ0-MLKE-K03V.

11. Colley Jr., J. L., Doyle, J. L., Logan, W. G., Stettinius, W. (2005). What is Corporate Governance. - New York: McGrow-Hill.

12. De Andres, P., Azofra, V., Lopez, F. (2005). Corporate Boards in OECD Countries: size, composition, functioning and effectiveness // Corporate Governance: An International
Review. Vol. 13, No. 2, pp. 197-210. doi: 10.1111/ j.1467-8683.2005.00418.x.

13. Drucker, P. (1974). Management: Tasks, Responsibilities, Practices. - New York: Harper and Row.

14. Eisenhardt, K. (1989). Agency Theory: An Assessment and Review // Academy of Management Review. Vol. 14, No. 1, pp. 57-74. doi: 10.5465/ AMR.1989.4279003.

15. Florackis, Ch., Ozkan, A. (2009). The Impact of Managerial Entrenchment on Agency Costs: An Empirical Investigation Using UK Panel Data // European Financial Management. Vol. 15, No. 3, pp. 497-528. doi: 10.1111/j.1468-036X.2007.00418.x.

16. Greco, G. (2010). Determinants of board and audit committee meeting frequency // Managerial Auditing Journal. Vol. 26. No. 3, pp. 208-229. doi: 10.1108/02686901111113172.

17. Green, W. H. (2003). Econometric Analysis. New Jersey: Prentice Hall.

18. Gujarati, D. (2003). Basic Econometrics. - New York: McGraw Hill.

19. Hermalin, B. E., Weisbach, M. S. (1991). The effects of board composition and direct incentives on firm performance // Financial Management. Vol. 20. No. 4, pp. 101-112.

20. Hillman, A. J., Cannella, A. A., Paetzold, R. L. (2000). The Resource Dependence Role of Corporate Directors: Strategic Adaptation of Board Composition in Response to Environmental Change // Journal of Management Studies. Vol. 37, No. 2, pp. 235-256. doi: 10.1111/14676486.00179.

21. Holderness, C. G. (2003). A survey of blockholders and corporate control // Economic Policy Review. Vol. 9, No. 1, pp. 51-64.

22. Hsiao, Ch. (2003). Analysis of Panel Data. Cambridge: Cambridge University Press.

23. Hung, H. (1998). A Typology of the theories of the roles of governing boards // Corporate Governance: An International Review. Vol. 6, No. 2, pp. 101-111. doi: 10.1111/1467-8683.00089.

24. Jensen, M. C. (1993). The modern industrial revolution, exit, and the failure of internal control systems // The Journal of Finance. Vol. 48, pp. 831-880. doi: 10.1111/j.1540-6261.1993. tb04022.x.

25. Jensen, M. C., Meckling, W. H. (1976). Theory of the Firm: Managerial Behavior, Agency Cost and Ownership Structure // Journal of Financial 
Economics. Vol. 3, No. 4, pp. 305-360. doi: http:// dx.doi.org/10.1016/0304-405X(76)90026-X.

26. Jezak, J. (2010). Lad korporacyjny: Doswiadczenia swiatowe oraz kierunki rozwoju. - Warszawa: C.H. Beck.

27. Jungmann, C. (2006). The Effectiveness of Corporate Governance in One-Tier and TwoTier Board Systems // Company and Financial Law Review. Vol. 4, pp. 426-474. doi: 10.1515/ ECFR.2006.019.

28. Kang, H., Cheng, M., Gray, S. J. (2007). Corporate Governance and Board Composition: diversity and independence of Australian boards // Corporate Governance: An International Review. Vol. 15, No. 2, pp. 194-207. doi; 10.1111/ j.1467-8683.2007.00554.x.

29. Kiel, G., Nicholson, G. (2003). Board Composition and Corporate Performance: How the Australian Experience Informs Contrasting Theories of Corporate Governance // Corporate Governance: An International Review. Vol. 11, No. 3, pp. 189-205. doi: 10.1111/1467-8683.00318.

30. Kochhar, R., David, P. (1996). Institutional Investors and Firm Innovation: A Test of Competing Hypotheses // Strategic Management Journal. Vol. 17, No. 1, pp. 73-84.

31. Kojima, K. (1997). Japanese corporate governance: an international perspective. - Research Institute for Economics \& Business Administration, Kobe University: Kobe.

32. Koladkiewicz, I. (2011). Budowa skutecznych rad dyrektorow/rad nadzorczych - wazne wyzwanie dla akcjonariuszy / In Komitety rad nadzorczych, ed. D. Dobija, I. Koladkiewicz, I. Cieslak and K. Klimczak, - Warszawa: Oficyna, pp. 15-38.

33. Kosnik, R. D. (1987). Greenmail: A study of board performance in corporate governance // Administrative Science Quarterly. Vol. 32, No. 2, pp. 163-185.

34. Laksamana, I. (2008). Corporate board governance and voluntary disclosure of executive compensation practices // Contemporary Accounting Research. Vol. 25, No. 4, pp. 11471182 .

35. Lorsch, J. W., MacIver, E. (1989). Pawns or Potentates: The Reality of America's Corporate Boards. - Boston: Harvard Business School Press.

36. Mace, M. L. (1971). Directors: Myth and Reality. - Boston: Harvard Business School Press.

37. Maddala, G. S. (2008). Ekonometria. - Warszawa: Wyd. Naukowe PWN.
38. Mallin, Ch. A. (2009). Corporate governance. Oxford: Oxford University Press.

39. Mendez, C. F., Garcia, R. A. (2007). The effects of ownership structure and board composition on the audit committee meeting frequency: Spanish evidence // Corporate Governance: An International Review. Vol. 15, No. 5, pp. 909-922. doi: 10.1111/j.1467-8683.2007.00619.x.

40. Menon, K., Williams, J. D. (1994). The Use of Audit Committees for Monitoring // Journal of Accounting and Public Policy. Vol. 13, No. 2, pp. 121-139. doi: http://dx.doi.org/10.1016/02784254(94)90016-7.

41. Mizruchi, M. (1983). Who controls whom? An examination of the relation between management and boards of directors in large American corporations // Academy of Management Review. Vol. 8, No. 3, pp. 426-435. doi: 10.5465/ AMR.1983.4284426.

42. Morck, R., Shleifer, A., Vishny, R. W. (1988). Management Ownership and Market Valuation: An Empirical Analysis // Journal of Financial Economics. Vol. 20, pp. 293-315. doi: http://dx.doi. org/10.1016/0304-405X(88)90048-7.

43. Nielsen, S., Huse, M. (2010). Women directors' contribution to board decision-making and strategic involvement: The role of equality perception // European Management Review. Vol. 7, No. 3, pp. 16-29. doi: 10.1057/emr.2009.27.

44. Oviatt, B. (1988). Agency and Transaction Cost Perspectives on the Manager-shareholder Relationship: Incentives for Congruent Interest // Academy of Management Review. Vol. 13, No. 2, pp. 214-225. doi: 10.5465/AMR.1988.4306868.

45. Pfeffer, J., Salancik, G. (1978). The External Control of Organizations: A Resource Dependence Perspective. -New York: Harper\&Row.

46. Pugliese, A., Bezemer, P. J., Zattoni, A., Huse, A., Van den Bosch, F. A. J., Volberda, H. W. (2009). Boards of Directors' Contribution to Strategy: A Literature Review and Research Agenda // Corporate Governance: An International Review. Vol. 17, No. 3, pp. 292-306. doi: 10.1111/ j.1467-8683.2009.00740.x.

47. Rosenstein, S., Wyatt, J. (1990). Outside Directors, Board Independence, and Shareholder Wealth // Journal of Financial Economics. Vol. 26, No. 2, pp. 175-191. doi: http://dx.doi. org/10.1016/0304-405X(90)90002-H.

48. Rudolf, S., Janusz, T., Stos, D., Urbanek, P. (2002). Efektywny nadzor korporacyjny. - Warszawa: PWE. 
49. Shleifer, A., Vishny, R. W. (1997). A survey of corporate governance // Journal of Finance. Vol. 52, No. 2, pp. 737-783. doi: 10.1111/j.15406261.1997.tb04820.x.

50. Spira, L. F., Bender, R. (2004). Compare and Contrast: perspectives on board committees // Corporate Governance: An International Review. Vol. 12, No. 4, pp. 489-499. doi: 10.1111/ j.1467-8683.2004.00389.x.

51. Spisto, M. (2005). Unitary Board and Two-tiered Board for the New South Africa? // International Review of Business Research Papers. Vol. 1, No. 2, pp. 84-99.

52. Stiles, P. (2001). The impact of the board on the strategy: An empirical examination // Journal of Management Studies. Vol. 38, pp. 627-650. doi: 10.1111/1467-6486.00252.

53. Terjesen, S., Sealy, R., Singh, V. (2009). Women Directors on Corporate Boards: A Review and Research Agenda // Corporate Governance: An International Review. Vol. 17, No. 3, pp. 320-337. doi: 10.1111/j.1467-8683.2009.00742.x.

54. The European Commission (2009). Study on Monitoring and Enforcement Practices in Corporate Governance in the Member States.
Internet access: <http://ec.europa.eu/internal_ market/company/ecgforum/studies_en.htm>, [accessed May 23, 2014].

55. Tricker, B. (2009). Corporate Governance: Principles, Policies, and Practices. - Oxford: Oxford University Press.

56. Vafeas, N. (1999). Board meeting frequency and firm performance // Journal of Financial Economics. Vol. 53, pp. 113-142. doi: http://dx.doi. org/10.1016/S0304-405X(99)00018-5.

57. Westphal, J. D., Zajac, E. J. (1997). Defections from the Inner Circle: Social Exchange Reciprocity, and the Diffusion of Board Independence in U.S. Corporations // Administrative Science Quarterly. Vol. 42, No. 1, pp. 161-183.

58. Zahra, S. Pearce, J. (1989). Boards of Directors and Corporate Financial Performance: A Review and Integrative Model // Journal of Management. Vol. 15, No. 2, pp. 291-334. doi: 10.1177/014920638901500208.

59. Zona, F., Zattoni, A., Minichilli, A. (2013). A Contingency Model of Boards of Directors and Firm Innovation: The Moderating Role of Firm Size // British Journal of Management. Vol. 24, pp. 299315. doi: 10.1111/j.1467-8551.2011.00805.x.

The paper submitted: May 10, 2014 Prepared for publication: June 02, 2014

\section{Leszek BOHDANOWICZ \\ NUOSAVYBĖS VALDYMAS IR PRIEŽIŪROS TARYBOS VEIKLA LENKIJOS LISTINGUOJAMOSE BENDROVĖSE}

\section{S a n t r a u k a}

Iki šiol daugiausia diskutuojama buvo dèl bendrovių tarybos veiklos ir tos diskusijos dažniausiai rèmèsi atstovavimo teorijomis. Šis tyrimas, priešingai, remiasi hegemonijos teorija, kuri pasirodè yra naudinga, siekiant apibrèžti santykius tarp i̇monès vadovų ir jos priežiūros tarybos narių bendrovèse, kuriose dominuoja korporatyvinis valdymas. Ankstesni tyrimai pabrèžè įmonių valdybos svarbą ịmonès vertès kūrimui, susijusiam su akcininkų rizikos mažinimu, tačiau dabartinis supratimas apie jų vaidmenị įmoneje turi daug neatsakytų klausimų. Visų pirma, dauguma tyrimų išskyrè vienos pakopos valdymą, kai tuo tarpu mažai yra žinoma apie dviejų pakopų valdymą. Tai ypač susiję su bendrovès priežiūros tarybos veiklos efektyvumu. Iki šiol atlikti tyrimai rodè priežiūros tarybos pasyviąją veiklos pusę, tačiau nebuvo pakankamai ištirtos to priežastys. Šiame tyri- me siekiama pateikti išsamesnes įžvalgas ir parodyti valdybos su nuosavybès teise ir priežiūros tarybos narių atliekamas funkcijas. Antra, dauguma ankstesnių tyrimų buvo grindžiami remiantis atstovavimo teorijų požiūriu. Šis tyrimas paremtas hegemonijos teorija ir parodo kaip nuosavybès valdymas sumažina stebėtojų tarybos vaidmenị. Šio darbo tikslas yra išaiškinti, kaip nuosavybès valdymas veikia įmonès priežiūros tarybos narių darbą.

Tyrimui atlikti buvo pasirinktos bendrovès, apimant trijų metų laikotarpị nuo 2010 m. iki 2012 m., ir atliekant specialiųjų duomenų analizę (ilgalaikio poveikio modelis). Tyrimo imtị sudarè 207 Lenkijos įmonès, įtrauktos i Varšuvos vertybinių popierių biržą, kurios pateike 463 metines pastabas. Šio tyrimo rezultatai parodè, kad savininkų valdyba daro neigiamą ittaką priežiūros tarybos narių 
skaičiui. Taip pat, rezultatai patvirtino hipotezę, kad savininkų valdyba menkina priežiūros tarybos narių veiklą bei mažina jų gebejjimą vykdyti kontrolès funkcijas. Dar daugiau, ši analizè identifikavo keletą ryšių tarp priklausomų ir kontroliuojamų kintamųjų, įskaitant neigiamą ryši tarp tarybos posedžių dažnumo ir i̇monès dydžio, teigiamus santykius tarp tarybos komitetų skaičiaus ir stebètojų tarybos dydžio bei neigiamo ryšio tarp tarybos komitetų skaičiaus ir i̇monès skolos santykio.

Apibendrinant galima teigti, kad neigiamas ryšys tarp savininkų valdybos ir priežiūros tarybos veiklos atitinka ankstesnių tyrimų patvirtintą vienos pakopos valdymo modeli, tačiau šiame tyrime norima parodyti, kad dviejų pakopų valdybos modelis nepadidina priežiūros tarybos veiklos trūkumų.
Atsižvelgiant $\mathfrak{i}$ tai, šis tyrimas gali būti naudojamas kaip atskaitos taškas diskusijai dèl institucinių pakeitimų Lenkijos dviejų pakopų valdymo modelyje ir kitų šalių institucijoms, kurios šiuo metu atlieka reformas. Pirma, reikètų apsvarstyti alternatyvų valdymo modeli (pasirinkti tarp vienos ir dviejų pakopų modelių) šalyse, kur egzistuoja dviejų pakopu valdymo modeliai. Alternatyvus modelis leidžia lanksčiai pritaikyti įmonių priežiūros valdybos struktūrą ir nuosavybès valdymo struktūrą, priklausomai nuo sektoriaus tipo, dydžio ir veiklos kiekio. Antra, būtų tikslinga taikyti panašią išorinių ir vidinių įmonès vadovų atsakomybę. Tokiu atveju vadovai būtų mažiau linkę toleruoti priežiūros tarybos narių veiklos sumažèjimą. Abi šios galimybès gali pagerinti immonių valdybos veiklą. 